University of Rhode Island

DigitalCommons@URI

$4-15-2014$

\title{
Policy Change and Venue Choices: Field Burning in Idaho and Washington
}

Aaron J. Ley

University of Rhode Island, ajley@uri.edu

Edward P. Weber

Follow this and additional works at: https://digitalcommons.uri.edu/psc_facpubs

Terms of Use

All rights reserved under copyright.

\section{Citation/Publisher Attribution}

Aaron J. Ley \& Edward Weber (2014) Policy Change and Venue Choices: Field Burning in Idaho and Washington, Society \& Natural Resources, 27:6, 645-655, DOI: 10.1080/08941920.2014.901461

Available at: http://dx.doi.org/10.1080/08941920.2014.901461

This Article is brought to you for free and open access by the Political Science at DigitalCommons@URI. It has been accepted for inclusion in Political Science Faculty Publications by an authorized administrator of DigitalCommons@URI.For more information, please contact digitalcommons-group@uri.edu. 
Policy Change and Venue Choices:

Field Burning in Idaho and Washington

\author{
Aaron J. Ley, Ph.D. \\ Assistant Professor \\ University of North Dakota
}

Edward P. Weber

Professor

Oregon State University

Accepted: Society \& Natural Resources 05/22/2013 
The pursuit of policy change is an age-old political activity and is often driven by political interests representing changing societal values and practices at odds with the legal status quo. Groups seeking change pursue their preferences in policy venues--"the institutional locations where authoritative decisions are made concerning a given issue" (Baumgartner and Jones 1993, 32)—such as legislatures, courts, administrative agencies, and, increasingly, collaboratives. But the question is: what policy venues do groups tend to choose and why? We offer insights into this puzzle by examining field burning policy in Washington and Idaho.

Bluegrass seed is used for lawns and golf courses, and eastern Washington State and northern Idaho are major contributors to national and international markets. Starting in the late 1940s the primary method for ensuring increased productivity is field burning, or the burning of crop residue. Burning "shocks" plants into production, exposes them to more sunlight, and helps control the growth of weeds. The practice also minimizes labor costs and soil erosion, while maximizing profits. Without field burning, farmers replant every three to four years, whereas burned fields remain planted for six to eight years.

Field burning also increases public health risks. Efforts to minimize the impact of smoke by burning when favorable weather conditions permit are often foiled by unpredictable wind patterns, thus pushing the smoke into the more densely populated urban areas of Spokane, Washington and Couer d'Alene, Idaho. More generally, because smoke drifts across county or state lines, efforts to regulate the practice by single jurisdictions tend not to work. The elderly and those with respiratory illnesses are affected most, with many area doctors advising those with 
asthma and cystic fibrosis to stay indoors or take vacations during the field burning season from August through October. The smoke also deters tourists and recreational enthusiasts from enjoying the area's beautiful forests, rolling hills, streams and lakes, and abundant wildlife.

By the early 1990s, these negative externalities created mounting pressure for policy change by diminishing public acceptance of long-standing policies that allowed relatively unrestricted field burning in both states. Environmentalists in Idaho and Washington seized on this opportunity to pursue policy change, and eventually met with significant success in changing state field burning policies, resulting in more burning restrictions and cleaner air. Yet the same policy goals were pursued in different institutional venues, with environmentalists choosing the court venue twice in Idaho, while Washington advocates opted for collaboration before pursuing, with success, a mixed venue strategy employing a local administrative-legislative venue coupled with a state-level administrative venue.

What explains the different venue choices? Did environmental groups, finding themselves blocked in certain venues, and per Schattschneider (1960), choose to expand the scope of conflict as a way of increasing their chance of success? Or, as the Advocacy Coalition Framework (ACF) argues, because groups are often simultaneously involved in a number of different venues with regard to specific policy issues (Weible 2007), did they strategically apply their resources "to produce the most policy benefits for the cost incurred" (Sabatier and Jenkins-Smith 1999, p. 142)? Or, was the logic of choice more consistent with Pralle (2003), namely that internal group constraints deter groups from moving into new venues 
because "policymakers and advocacy groups have pre-existing preferences for certain venues, ... [which means that] [f]ailure in one venue, or the existence of opportunity in another, does not necessarily mean that an advocacy group will shift venues" (p. 242; see also Pralle 2010)?

The data presented in our comparative analysis offer support for both Schattschneider and ACF, but not Pralle. Finding themselves blocked and/or facing less than satisfactory outcomes in certain policy venues, environmentalists in both cases expanded the scope of conflict. They also strategically targeted their efforts at venues which best matched their political, legal and technical (informational) resources in a bid to promote policy change successfully. Yet, precisely because environmentalists were willing in Washington to switch venues as their coalitional resources changed, they clearly were not tied firmly to any pre-existing venue preferences ala Pralle. Moreover, in the Idaho case we find that SAFE chose federal courts not from any predetermined preferences, but rather as a rational, strategic response since they were shut out of other possible venues.

More importantly, these cases highlight a key oversight in the growing literature on venue choice theory. Current theory focuses entirely on venue choice as the key to policy change and, by doing so, treats the "group" pressing for change as a static, unchanging entity. Our findings, however, demonstrate that successful policy change requires both appropriate venue selection and coalitional change, or alliances with others rich in key political, technical and legal resources lacking in the primary group pushing for change. This means that policy venue theory will benefit to the extent it can integrate the established lessons provided by Lowi (1979), 
namely that eventual success in defeating a long-established status quo typically requires a strengthening of the original group in order to increase the group's leverage vis-à-vis opponents.

\section{Research Methodology}

We employ a multiple case study design appropriate for research questions that require in-depth contextual analysis to answer "how" or "why" a phenomenon occurs (Yin 2009). We limit analysis to the problem of field burning, a policy conflict that occurred over more than ten years that pitted the value of public health against agricultural economic productivity. In addition, the jurisdictions examined here Eastern Washington and North Idaho - are geographically proximate and culturally similar, and meet the test of "similar cases" as posed by Gerring (2001): "The mostsimilar research design looks for a few cases that are as similar as possible in all respects except the outcome of interest, where they are expected to vary" (p. 210). ${ }^{1}$

We employed a snowball sampling method of key stakeholders, and, in 2008 and 2009 conducted semi-structured interviews with 35 farmers, industry officials, government employees, legislators, journalists, political activists, and attorneys involved in the field burning controversy. We also relied on newspaper archives, archival data from public hearings, and newsletters from key organizations to establish facts through a method of "convergence" — when multiple sources confirm the same fact (Yin 2009).

\footnotetext{
${ }^{1}$ In both the Idaho and WA cases there were four of the same possible venue choices, each providing the opportunity for policy change: (1) courts, (2) state legislature, (3) state "administrative" agencies, and (4) collaboratives. Washington did offer a $5^{\text {th }}$ venue in SCAPCA - the local legislative-administrative agency. Yet, even with SCAPCA, the State Dept. of Ecology and legislature controlled policy.
} 


\section{Idaho Field Burning Goes to Court}

Growing evidence of field burning's public health hazards led to the formation of Safe Air For Everyone (SAFE) in 2001 and its subsequent clash with the North Idaho Farmers Association (NIFA). Initially consisting of a mix of public health advocates from the medical community (e.g., Idaho Medical Association) and clean air advocates (American Lung Association), SAFE quickly added members from the Northern Idaho real estate industry given declines in property value tied to burning, as well as tourism interests and several local Chambers of Commerce. By 2002 SAFE's membership had climbed to 400 (Olsen and Hollander 2001). This group targeted two policy venues from 2002 to 2006.

\section{Choosing the Federal Courts}

The immediate challenge for SAFE was that its primary foe, NIFA, was well integrated into Idaho's political infrastructure and had made protecting field burning a top priority for decades (Sudermann 1998). NIFA's advantages started with Idaho's well entrenched, strongly conservative politics. This meant that state laws, with few exceptions, favored agricultural productivity and economic growth over environmental protection (Powers and Barrett 2001). Moreover, NIFA enjoyed financial leverage from self-assessed burning fees, which amounted to $\$ 25,000$ annually (personal correspondence, 11/13/12). Burning fees funded public relations and lobbying efforts, which, in cooperation with the Farm Bureau, 
translated into considerable state-level legislative policy success (Powers and Barrett 2001; personal correspondence, 11/13/12) and, ultimately, a virtual dominance of state-level venues on field burning issues (Hedberg 2002). The passage of strong right-to-farm laws in 1980 and 2003 that precluded nuisance suits made state courts inhospitable to litigation challenging agricultural practices, even when they infringed on human health. In the 1980s, pressure and scientific studies from NIFA and its allies led the Idaho Department of Environmental Quality (IDEQ) to list field burning as an allowable source of pollution under Idaho's Clean Air Act (CAA) State Implementation Plan (SIP). Further, NIFA successfully lobbied to shift regulatory jurisdiction over field burning from IDEQ to the Idaho State Department of Agriculture (ISDA), an agency designed to promote agriculture (Hedberg 2002).

Given the successes of pro-agricultural forces, and their own limited political resources stemming from relatively small size and newness to the policy process, SAFE knew that state-level venues offered little hope for policy change. As one member stated, "there was no legislative solution. The legislature was part of the problem" (interview, 3/10/2010). The executive director of SAFE agreed:

\footnotetext{
The Legislature has never taken the lead on ensuring public health, so we'll continue to work any and all avenues that we can to make sure that the Legislature understands the ... crisis. We prefer not to go to court, but in the absence of any clear leadership, we will be prepared to take that step if we have to (Hedberg 2002).
}

At the same time, SAFE's access to legal talent, both in house and through allies, combined with the overall attractiveness of the federal courts venue, offered the highest likelihood for policy change. 
The federal courts were attractive for three main reasons. First, many federal environmental laws, especially those pertinent to field burning, offered stronger protection than Idaho law. Second, federal courts have a decades-long record of codifying and strengthening environmental laws, and offering the type of access not afforded by state legislative and administrative venues (Epp 1998). Finally, Idaho appeals go to the Ninth Circuit Court of Appeals, which is arguably the most liberal federal court, especially in the area of environmental litigation (Kagan 2004).

Thus, SAFE took to the federal courts in February 2002 alleging a violation of the Resource Conservation and Recovery Act (RCRA), an act regulating hazardous waste. SAFE argued that the burning of crop residue (waste) was not being properly regulated. Coupled with this legal strategy, SAFE made a concerted effort to produce adequate scientific support for their position by including [e]xpert witnesses retained to demonstrate that grass residue met the legal definition of agricultural waste as defined by RCRA; that the smoke making people ill was in fact originating from growers' fields, and that the high particulate readings on air quality monitors were correlated with symptoms in the general public complaint records. Air modeling was done to demonstrate how the clouds of smoke travel in the region.... Agronomic experts demonstrated that Kentucky bluegrass could be grown for at least a four year rotation without burning and without drops in yields (SAFE 2002).

Unfortunately for SAFE, the district judge dismissed the lawsuit, but not without hearing oral arguments and establishing a record of field burning's impact (Shors 2002). Ruling that burned crop residue does not constitute hazardous waste and 
that he lacked jurisdiction, the judge wrote, "The Court finds the burning of residue is not a 'disposal' and, further, the residue is not a 'solid waste' because it is neither discarded or abandoned, but instead, used as part of the growth process. Therefore RCRA does not apply" (Alkire 2002). After unsuccessfully appealing this ruling to the Ninth Circuit, SAFE regrouped and made its next venue choice.

\section{Back to the Future in Idaho: Choosing Federal Courts Again}

SAFE's loss did not deter them from choosing federal courts again in 2006 although this choice had less to do with an overall preference for litigation. After all, litigation is costly and adversarial and members of SAFE expressed doubts about litigation as a continued strategy (interviews 2009). In the meantime, SAFE also supported efforts to build a stronger scientific case against field burning. In fact, despite losing the RCRA court case, SAFE built a body of evidence demonstrating the harmful impact of field burning.

We had epidemiologists, we had toxicologists, ... we created so much evidence for th[e RCRA case].... Getting the experts that typically only rich industry can afford. We ... had the money and ... did it (interview, 10/28/2009).

In addition, the case helped SAFE build new professional relationships with attorneys involved in federal public health litigation. These lawyers included those from the Sierra Club's legal arm, Earthjustice. Having access to high-powered and experienced legal expertise did two things that strongly influenced SAFE's second venue decision. First, the appeal of the RCRA case "softened up" the Ninth Circuit 
and established a set of facts and scientific support that made it more likely to accept that field burning was harmful (interview, 10/28/2009).

Second, the consultation with Earthjustice lawyers led to the discovery of a potential flaw in Idaho's SIP, a new legal angle to get the controversy in front of the federal Ninth Circuit again. Due to an error while revising its SIP in 2003, field burning was not officially articulated as an allowable source of air pollution by Idaho lawmakers (Smith 2005). Lawmakers were made aware of this omission and quickly amended the SIP, which the EPA approved. Yet this response was deemed inadequate and lacking legality because, according to SAFE, EPA had violated the 1946 Administrative Procedures Act (APA) by failing to adequately consider the negative health and visual impacts of the "new" amendment (Smith 2005).

The appeal of EPA's decision went directly to the Ninth Circuit ${ }^{2}$ and, in 2007, it ordered EPA to reconsider its approval of field burning in Idaho (Dukes 2007). The decision forced farmers and grass growers to the bargaining table and, by January 2008, an agreement was reached between growers and SAFE establishing a new smoke management program. The new program ensured stronger human health protections than federally mandated levels under the Clean Air Act for the pollutant of chief concern, small particulate matter, and others such as carbon monoxide, ground-level ozone (urban smog), and sulfur dioxide. Specifically, "no burns are allowed if any of the criteria pollutants under the Clean Air Act are at or predicted to reach $75 \%$ of federal levels" (SAFE 2012). In addition, the agreement

\footnotetext{
${ }^{2}$ The CAA allows appeals of administrative decisions to the Circuit Courts (42 U.S.C. § 7607).
} 
returned state-level regulatory jurisdiction from the farmer-controlled ISDA to IDEQ, Idaho's primary pollution control agency (Buley and Stewart 2008).

\section{Field Burning in Washington: A Multi-Venue Strategy}

In 1998, the State of Washington became the first state in the Pacific Northwest to ban field burning, most all of which occurred around the eastern city of Spokane (population: 250,000). Just like in Idaho, Washington citizens banded together in 1995 to form Save Our Summers (SOS) for the purpose of eliminating the practice. Yet, instead of choosing the courts, clean air advocates chose a collaborative venue first, before expanding the scope of conflict by selecting a two venue strategy that focused on a state-level administrative venue and a local administrative-legislative (elected board) venue in eastern Washington.

\section{Trying the Collaborative Venue First}

In Washington State, the Department of Ecology (DOE) exercised jurisdiction over pollution, including field burning. Yet Washington's 1967 Clean Air Act (CAA) transferred primary regulatory authority for air pollution to county-based agencies that were governed by executive boards made up of elected officials. In Spokane County the local air pollution agency was the Spokane County Air Pollution Control Authority (SCAPCA). ${ }^{3}$ During the 1970 s and 1980s SCAPCA was dominated by profield burning forces, chief among them the Intermountain Grass Growers

\footnotetext{
${ }^{3}$ SCAPCA was later renamed Spokane Clean Air.
} 
Association (IGGA), a group financed through self-assessed per-acre burning fees that not only lobbied SCAPCA, but also made sure its members attended public meetings regularly and defended members against lawsuits (interviews 2009; Yates 1990). The self-assessed "burn" fees of between $\$ 2$ and $\$ 3$ per acre in the late 1980s through the late 1990s produced annual support for IGGA in the range of $\$ 70,000$ to $\$ 105,000 .^{4}$

Things began to change in 1987 when Spokane County violated federal CAA standards for small particulate matter, thus forcing SCAPCA to consider new regulations in 1990 that reduced the numbers of acres to be burned from roughly 31,000 in 1990 to 18,108 in year 2000, and created a limited "window" of time for burning regardless of weather conditions (Yates 1990). Over 200 members of the grass growing community reacted by turning out at public hearings to oppose the new rules, while little more than a dozen citizens testified in favor of stricter controls (Bayne 1990). In the end, IGGA succeeded in watering down the new rules by increasing the burning "window" by 33 percent, increasing the 1990 baseline to 35,000 acres, and allowing field burning to continue into the indefinite future. Such dominance in turnout at public SCAPCA meetings was par for the course. From the late 1980s through 1995, growers and their agricultural allies tended to pack meetings with 90 percent of all attendees in support of growers' pro-field burning position (Steele 1995a).

\footnotetext{
${ }^{4}$ The number of acres being burned each year in the late $1980 \mathrm{~s}$, and the number that made it into new SCAPCA rules in 1990 as a baseline for policy, was 35,000 acres, on average (SCAPCA 1990; Yates 1990).
} 
The rulemaking result dissatisfied a growing number of residents in and around Spokane, and led key stakeholders to seek a negotiated collaborative process. Clean air advocates knew that, by definition, a collaborative forum gave them a fighting chance of influence because its primary purpose was to produce win-win, positive sum outcomes in which all stakeholders are made better off than before. Moreover, clean air advocates were not the only local stakeholders concerned about the negative effects posed by field burning. The Soil and Water Conservation Society (SWCS) led the way in 1990 with a position statement that decried how "[c]onflicting interests have become so polarized and emotion-charged that it may be very difficult to achieve a rational solution," while also calling for the "effective resolution of conflicts and resource use problems arising from this issue" (SWCS 1990, p. 2). The SWCS was quickly joined by the Ag Forestry Leadership group and the Agricultural Bureau of the Spokane Chamber of Commerce, long an ally of the local grass growers, and IGGA. Recognizing that "the grass seed industry is an important economic force in the region's economy" and declaring "the need to preserve and improve air quality," these groups joined clean air advocates, state and local agencies, and public health interests such as the American Lung Association (ALA), in the collaborative Inland Northwest Field Burning Summit that operated from 1990 to 1995 (Spokane Chamber of Commerce N.d.).

To no one's surprise the negotiations were not easy. One stakeholder identified several times where negotiations deteriorated: 
[T]oo many times, we had people walk out and throw their clipboards across the table and say "F__ you, I'm outta here" and one time I had to chase a guy down and I pinned him in the stall of the toilet ... and I wouldn't let him out (interview, AG2).

Despite the contentiousness, the collaborative effort reached areas of mutual agreement that served as a potential foundation for later compromises. By July 1991, summit stakeholders came to an agreement limiting the days, location, and the amount of acreage burned (AP 1991). Then, in May 1993 stakeholders agreed on an expression of intent going forward:

The 1993 INFB Summit members, recognizing that portions of our earlier field burning agreement are now dated, agree unanimously to support the principles embodied within that agreement and to actively pursue as a group and individually the ultimate goal of eliminating grass burning by the development of practical alternatives that will allow continued production of grass seed (INFB Summit 1993).

Acreage caps on burning were finally established after summit participants acknowledged that smoke from field burning contributed to major air pollution problems in Spokane, especially small particulate matter (Steele 1994).

By August 1994, however, the coalition and its collaborative agreements began unraveling. The ALA chapter announced its intention to quit the summit because it was settling for "amelioration," not a "fixed plan to ... stop ... burning. To tolerate this ... is unacceptable (ALA 1994). For their part, many growers found the newly imposed acreage limits and "window" for burning too restrictive and costly. In any event, the collapse of the collaborative effort was hastened with the 1994 mid-term elections that produced a Republican takeover of the Washington House 
of Representatives and a near takeover of the Senate. Growers abandoned the local collaborative effort to seek out a state-based legislative solution more to their liking, which they did in 1995 by statutorily limiting SCAPCA's power to put limits on the number of days growers could burn (Camden 1995).

\section{Targeting Local and State Venues Simultaneously}

The new legislation ignited an organized public backlash against field burning and led to the formation of SOS, a grassroots Eastern Washington group, in 1995. SOS described its founding and mission:

[We] believe that this region should be a beautiful and healthy place for all of us to breathe and raise our children. We were created ... after the bluegrass industry ... persuaded legislators ... to further de-regulate grass burning by stripping local air pollution control authorities of their powers to limit ... burning (SOS 1996).

Ramping up quickly with over 500 members, SOS challenged the grass growers simultaneously in two different venues.

A Local Legislative-Administrative Venue. The first part of the two-pronged venue strategy matched their primary, yet localized strength of mobilized citizens with the increasingly contested, and therefore increasingly accessible, SCAPCA venue. A new SCAPCA Director in 1993 and a newly elected board member in 1995, both sympathetic to SOS's public health concerns, along with a five-fold increase in citizen complaints in 1995, helped turn the tide. The rapid erosion of growers' dominance was also evident by the turnaround in the mix of attendees at SCAPCA's 
meetings. Instead of 90 percent favoring growers, meetings from 1995 through 1997 contained 80 to 90 percent attendees against field burning (Steele 1995a).

At the same time, SOS started gathering medical/health harm data from field burning, and cultivated support from Spokane's large medical community and the ALA. SOS won medical community support for a burn ban because "physicians ... serving patients in the area ... believed that ... the scientific information showed that the smoke was a hazard.... One physician ... surveyed the [Spokane County Medical Society] [as] to whether grass-burning smoke was a health problem.... [0]f 600 members, 580 responded, yes, it was" (McLeod 2005).

SOS's choice of the local administrative-legislative venue was was instrumental in a 3 - 2 vote by SCAPCA in December 1995 to phase-out field burning completely in Spokane County by 2002 (Steele 1995b).

A State Level Administrative Venue. The overarching role played by Washington State's Department of Ecology (DOE) in air pollution matters, the blockage of the state legislative venue by growers and their Republican allies, and the push by the Clinton Administration EPA to rewrite the rules for small particulate matter, led SOS to start building a relationship with DOE in 1995. The goal: to persuade DOE to further restrict and ban field burning in Washington State.

The choice of DOE also made sense to SOS, along with ALA and the Spokane medical community, two groups with considerable scientific resources , because they believed science was on their side (interview, 01/20/2009). The science against field burning found additional support in several EPA-recognized Harvard 
epidemiological studies demonstrating the link between mortality and exposure to particulate matter (Schwartz, et al. 1996; interview, 02/22/2010). The choice of DOE as a venue was also attractive to SOS because, of all the environmental and natural resources agencies in Washington, DOE had the strongest reputation as a supporter of public health values (interview, 01/20/2009).

The decision to work at both the local level and with DOE started paying dividends in 1996. After the new SCAPCA phase-out rules in December 1995, growers asked DOE to strip SCAPCA of its regulatory authority over burning and to craft new statewide rules protecting field burning (Steele 1996a). Yet DOE officials resisted, concluding that the growers, by doing an end run to the legislature around the earlier collaborative bargaining effort, had acted in bad faith. More important was that the new scientific evidence brought to bear by SOS and its allies, which linked fine particulate matter to poor human health outcomes, was becoming impossible to ignore. A DOE official noted that "as we got better science about the consequences were [of field burning,] that ... added momentum and courage to ... agency [decision-makers]" (interview, 02/22/2010). As a result, DOE supported SCAPCA's decision to phase out burning and imposed a 120-day emergency fieldburning moratorium in late March 1996 (Steele 1996a). Later in 1996, DOE officially phased out the statewide practice of field burning (Steele 1996b), and DOE banned the practice statewide in 1998 after a Washington State University study concluded that the public health costs of burning outweighed the economic benefits (Holland et al. 1997). 


\section{Conclusion}

Environmental advocates in Washington and Idaho met with significant success in changing state policies associated with field burning. In each case, however, environmentalists and their allies chose different policy venues. The question is why? In both cases there is strong support for Schattschneider's (1960) finding that interest groups will expand the scope of conflict when particular policy venues are inhospitable to their demands. Yet, this analysis also shows that groups strategically match their political, legal, and technical resources to the appropriate venue in order to increase the likelihood of success in the new venue. In Idaho, state-level venues across the board were dominated by grass growers, along with their agricultural and industry allies. Thus it made sense, especially given SAFE's access to legal resources and the attractiveness of the federal courts, to expand the scope of conflict to the federal level. In Washington State, the story is the same. The lack of satisfaction with the regional collaborative forum led environmentalists to expand the conflict to two different, new venues that were a good match for their increasing political and technical resources.

These results are contrary to Pralle (2003) because the overall goal of policy change in both Washington and Idaho clearly overwhelmed any constraining effect imposed by ideology or culture. This is especially true in Washington when SOS generated greater political support from the public health community and was able to press their demands on a local legislative-administrative venue designed to be responsive to popular demands and a state administrative agency that was more responsive to the mobilization of scientific evidence. The Idaho case also supports 
this logic through the interview data from key case participants, as well as the testimonial from SAFE's Executive Director's that “we'll continue to work any and all avenues ... if we have to" (Hedberg 2002). In sum, the cases illustrate how interests view and strategically react to the larger institutional context when shopping for a policymaking venue most conducive to their policy goals (Sabatier and JenkinsSmith 1999).

These cases also demonstrate that any story of policy change is incomplete without understanding the importance of coalitional change. SAFE's ability to expand its coalition and resource base through new working relationships with Earthjustice lawyers and outside medical experts figured centrally in their second, successful use of the federal courts. Nor is the story of policy change in Washington complete without the influence of new coalitional resources and allies. The new scientific evidence from EPA/Harvard studies and the Spokane medical community linking fine particulate matter to poor human health outcomes allowed SAFE access to and influence in Washington's Department of Ecology, while the successful mobilization of citizens was critical to change at the local administrative-legislative forum (SCAPCA). Seen from this perspective, the evidence suggests that venue choice research can be enriched if it expands its vision to focus on actual policy change and the importance of changing coalitions and resources.

\section{References}

ALA. 1994. "End to Burning Overriding Concern," The Spokesman Review, 7 Oct 1994, Sec. B.

Associated Press. 1991. "Grass Growers Agree to Limit Field Burning," The Spokesman Review, 21 Jul 1991, Sec. B

Alkire, Tom. 2002. Bureau of National Affairs Daily Environment Report, 24 July 2002, Washington, D.C. 
Bayne, Nedra. 1990. "Officials Dampen Hopes of Growers," Agri-Times, 23 Mar 1990, Vol. 6, No. 29.

Buley, Bill, and Marc Stewart. 2008. "Deal Brings Back Field Burning," The Coeur d'Alene Press, 12 January 2008, Sec. A.

Camden, Jim. 1995. "Clash Expected over Burning Regulations Change in Law," The Spokesman Review, 19 July 1995, Sec B.

Dukes, Lucy. 2007. "Farmers Look for Answers to Field-Burning Ban," The Coeur d'Alene Press, 14 March 2007.

Epp, Charles. 1998. The Rights Revolution. Chicago: University of Chicago Press.

Hedberg, Kathy. 2002. "SAFE will Sue to Stop Burning," Lewiston Morning Tribune, 7 February 2002, Sec. A.

Holland, David, Kathleen Painter, R. Douglas Scott, Philip Wandschneider, and David Willis. 1997. "Estimates of the Benefits and Costs from Reductions in Grass Seed Field Burning." Olympia, WA: Washington Department of Ecology.

INFB. 1993. "Meeting Minutes," 18 May 1993, Washington State University.

Kagan, Robert A. 2004. "American Courts and the Policy Dialogue: The Role of Adversarial Legalism." In Making Policy, Making Law, eds. Mark C. Miller and Jeb Barnes. Washington, D.C.: Georgetown University Press.

McLeod, Maria. 2005. Washington State Department of Ecology Historically Speaking: An Oral History of the First 35 Years, 1970-2005. Olympia, WA: Washington State Department of Printing.

Olsen, Ken, and Zaz Hollander. 2001. "Solution to Torching Grass Fields Still Hazy," The Spokesman Review, 8 August 1999, Sec. B.

Powers, Thomas, and Richard Barrett. 2001. Post-Cowboy Economics: Pay and Prosperity in the New American West. Washington, D.C.: Island Press.

Pralle, Sarah B. 2003. "Venue Shopping, Political Strategy, and Policy Change." Journal of Public Policy 23: 233-260.

. 2010. "Shopping Around: Environmental Organizations and the Search for Policy Venues." In Advocacy Organizations and Collective Action, eds. Aseem Prakash and Mary Kay Gugerty. Cambridge, MA: Cambridge University Press.

Sabatier, Paul, and Henk Jenkins-Smith. 1999. "The Advocacy Coalition Framework: An Assessment," In Theories of the Policy Process, ed. Paul A. Sabatier. Boulder, CO: Westview Press.

SAFE. 2002. "Conflicting Missions: DEQ and ISDA - Smoke Management Efforts 2002," A White Paper.

SAFE. 2012. "Defending the public health from agricultural field burning in Idaho." Retrieved on November 5, 2012 from http://safeairforeveryone.org.

Save our Summers. 1996. "Newsletter." No Date. Spokane, WA: Spokane Clean Air. 4 $\mathrm{pp}$.

Schattschneider, E.E. 1960. The Semisovereign People. New York: Holt, Rinehart, and Winston.

Schwartz, Joel, D.W. Dockery, and L.M. Neas. 1996. "Is Daily Mortality Associated Specifically with Fine Particles?" Journal of the Air \& Waste Management Association 46: 927-939.

Shors, Benjamin. 2002. "Burn-Ban Suit Tossed," The Spokesman Review, 20 July 2002, Sec. A. 
Smith, Christopher. 2005. “Groups Sue EPA over Field Burning,” The Twin Falls Times-News, 10 September 2005.

Steele, Karen Dorn. 1994. "Feds Approve Study of Dirty Spokane Air: Research on City's Dust Particles will help Nation,” The Spokesman Review, 8 July 1994, Sec. B. . 1995a. "Roskelley Gets Seat on SCAPCA: New Commissioner Will Replace Phil Harris on Clean Air Board," The Spokesman Review, 2 Dec 1995, Sec. B. . 1995b. "Board Votes to Phase Out Field Burning," The Spokesman Review, 15 December 1995, Sec. A.

Sudermann, Hannelore. 1998. "Grass Seed Association May Split Up,” The Spokesman Review, 19 June 1998, Sec. A.

Weible, Christopher M. 2007. "An Advocacy Coalition Framework Approach to Stakeholder Analysis: Understanding the Context of California Marine Protected Area Policy." Journal of Public Administration Research and Theory 17: 95-117.

Yates, Scott. 1990. "Growers Await Burn Decision," Capital Press, 23 Mar 1990. Yin, Robert K. 2009. Case Study Research: Design and Methods, Fourth Edition. Thousand Oaks, CA: Sage Publications. 